\title{
Pemanfaatan Ekstrak Ubi Ungu sebagai Pewarna Merah pada Soft Candy dan Stabilitasnya
}

\author{
Utilization of Purple Sweet Potato Extract as Red Pigment on Soft Candy and Its Stability \\ Putu Timur Ina ${ }^{1}$, Gusti Ayu Kadek Diah Puspawati ${ }^{1 *}$, Gusti Ayu Ekawati ${ }^{1}$, \\ Gusti Putu Ganda Putra²
1Jurusan Ilmu dan Teknologi Pangan, Fakultas Teknologi Pertanian Universitas Udayana, Jl. Kampus Bukit Jimbaran, Badung, Bali 80361, Indonesia
2 Jurusan Teknologi Industri Pertanian, Fakultas Teknologi Pertanian Universitas Udayana, Jl. Kampus Bukit Jimbaran, Badung, Bali 80361, Indonesia
*Email: dipa_ftp@yahoo.com

Tanggal submisi: 10 Januari 2018; Tanggal penerimaan: 4 Februari 2019

\begin{abstract}
ABSTRAK
Tujuan dari penelitian ini adalah menentukan konsentrasi ekstrak pewarna ubi ungu pada pembuatan soft candy dan stabilitasnya selama penyimpanan. Penentuan konsentrasi ekstrak pada pembuatan soft candy dilakukan melalui pengujian variasi konsentrasi ekstrak pewarna $(0,0,25,0,50,0,55$, dan $1 \%)$. Pengujian stabilitas pewarna selama proses penyimpanan dilakukan melalui penyimpanan soft candy pada variasi suhu refrigerator $\left(4^{\circ} \mathrm{C}\right)$, suhu kamar $\left(27^{\circ} \mathrm{C}\right)$ dan $35^{\circ} \mathrm{C}$ dengan periode pemeriksaan dilakukan setiap 2 hari selama 14 hari. Hasil penelitian formulasi soft candy dengan penambahan pewarna merah ekstrak ubi konsentrasi $0,75 \%$ memberikan nilai tertinggi pada penerimaan panelis terhadap penilaian sensori pada warna, aroma, tekstur, rasa dan penerimaan keseluruhan berturut-turut: 6,08 (suka); 4,02 (biasa); 5,58 (suka); 5,46 (agak suka); dan 5,92 (suka), dengan kadar antosianin, total fenolik dan aktivitas antioksidan berturut-turut: $12,74 \pm 0,06 \mathrm{mg} / 100 \mathrm{~g} ; 0,73 \pm 0,02 \mathrm{~g} / 100$ $\mathrm{g}$ dan $0,76 \pm 0,02 \mathrm{~g} \mathrm{AAE} / 100 \mathrm{~g}$. Stabilitas ekstrak pewarna soft candy selama penyimpanan pada suhu $35^{\circ} \mathrm{C}$ pada hari ke-14 terjadi penurunan nilai a* (kemerahan) dan peningkatan nilai b* (kekungingan), dan nilai $\mathrm{L}$ (kecerahan), sebagai indikator perubahan signifikan dari ekstrak pewarna merah ubi ungu pada soft candy, sedangkan pada suhu refrigerator $\left(4^{\circ} \mathrm{C}\right)$ dan suhu kamar $\left(27^{\circ} \mathrm{C}\right)$ sampai hari ke-14 belum menuju penurunan yang signifikan dari warna merah antosianin.
\end{abstract}

Kata kunci: Ekstrak ubi ungu; soft candy; stabilitas pewarna

\begin{abstract}
This study aimed to determine the purple sweet potato pigment extract concentration in soft candy formulation and its stability during storage. The research was conducted in two steps i.e. the addition of purple sweet potato pigment extract concentration in soft candy and of soft candy's red pigment stability during storage. Firstly, the soft candy formulation was added with the red pigment of purple sweet potato extract in various concentrations, i.e. control ( $0 \%$ extract); $0.25 \%$ concentration of the pigment extract; $0.50 \% ; 0.75 \%$; and $1 \%$. Secondly, the stability examination of pigment extract in soft candy was carried out at various storage temperatures: at refrigerator temperature $\left(4^{\circ} \mathrm{C}\right)$; at room temperature $\left(27^{\circ} \mathrm{C}\right)$; and at $35^{\circ} \mathrm{C}$ within the observation period of every 2 days for 14 days. The results showed that soft candy with the purple sweet potato red pigment extract addition of $0.75 \%$ concentration gave the highest value on panelists' acceptance in terms of color, odor, texture, taste and overall acceptance as follows: 6.08 (like); 4.02 (neutral); 5.58 (like); 5.46 (rather like); and 5.92 (like), respectively, with the following levels of anthocyanin, total phenolic and antioxidant activity: $12,74 \pm 0,06 \mathrm{mg} / 100 \mathrm{~g} ; 0,73 \pm 0,02$
\end{abstract}

DOI: http://doi.org/10.22146/agritech.32195

ISSN 0216-0455 (Print), ISSN 2527-3825 (Online) 
$\mathrm{g} / 100 \mathrm{~g}$ and $0,76 \pm 0,02 \mathrm{~g} \mathrm{AAE} / 100 \mathrm{~g}$, respectively. Stability of soft candy's red pigment extract during storage at a temperature of $35^{\circ} \mathrm{C}$ for 14 days showed a decline in the value of a* (redness), but an increase in the value of b* (yellowness) and the value of $L$ (brightness), as a significant indicator of the purple sweet potato red pigment extract color change on soft candy, meanwhile at refrigerator $\left(4^{\circ} \mathrm{C}\right)$ and room temperatures $\left(27^{\circ} \mathrm{C}\right)$ after 14 days observation has not shown the loss or a significant reduction of red pigment color.

Keywords: Pigment of purple sweet potato extract; soft candy; stability of pigment

\section{PENDAHULUAN}

Keanekaragaman produk yang berbasis pangan fungsional mulai menarik untuk dikaji. Hal ini seiring dengan meningkatnya penyakit tidak menular (PTM) yang disebabkan oleh pola makan atau gaya hidup yang kurang sehat. Pangan fungsional yang berbasis potensi komponen bioaktif dari bahan pangan alami juga mulai berkembang. Salah satu bahan pangan yang mengandung komponen bioaktif yang baik untuk kesehatan adalah ubi ungu. Ubi ungu memiliki warna ungu yang mengandung antosianin.

Antosianin merupakan salah satu komponen bioaktif yang berfungsi sebagai antioksidan dan pewarna alami. Sebagai antioksidan, antosianin dapat menekan radikal bebas. Radikal bebas sebagai ROS (reactive oxygen species) dan RNS (radical nitrogen species) merupakan molekul atau atom yang memiliki satu atau lebih elektron tidak berpasangan pada sisi luar orbitnya yang bersifat reaktif. Antioksidan dalam sistem tubuh akan berfungsi menekan radikal bebas sehingga dapat menekan terjadinya stres oksidatif. Sters oksidatif dalam sistem tubuh merupakan kondisi tidak ada keseimbangan antara radikal bebas dengan sistem pertahanan antioksidan. Stres oksidatif yang terus berlanjut akan menyebabkan kerusakan oksidatif. Kerusakan oksidatif dapat terjadi pada DNA, protein sehingga terjadi ganguan oksidatif dan penyakit tidak menular diantaranya: kanker, diabetes dan kardiovaskuler (Halliwell, 1994; Gilbert, 2006; Finosh \& Jayabalan, 2013).

Produksi ubi jalar yang terdiri dari ubi ungu secara nasional (Indonesia) rata-rata dari tahun 2012 sampai 2016 mencapai 2.328.612 ton. Produksi terbesar dengan kisaran produksi diatas 100 ton adalah Jawa Barat diikuti Papua, Jawa Timur, Sumatra Barat, Jawa Tengah dan Sumatra Utara. Bali menduduki urutan ke-10 yang produksinya sebesar 48.904 ton. Daerah produksi ubi jalar di Bali paling banyak yang kisaran produksi diatas 10 ton yaitu di Karangasem sebesar 14.206 ton, diikuti Bangli sebesar 11.729 ton. Produksi ubi jalar di Bali memang masih lebih rendah sekitar $57,4 \%$ dari ubi kayu yang produksi tahun 2015 sebesar 86.070.
Walaupun demikian, produksi ubi jalar ini penting dalam menunjang diversifikasi pangan sumber karbohidrat (BPS Bali, 2015; Retno dkk. 2016).

Pemanfaatan ubi ungu selain sebagai pangan seperti pemanfaatan tepung ubi ungu sebagai substitusi roti, juga potensial sebagai pewarna merah yang sehat dalam bentuk ekstrak ubi ungu (Iriyanti, 2012; Hambali dkk., 2014; Ina dkk., 2014). Aplikasi ekstrak ubi ungu sebagai pewarna merah pada pangan telah berkembang, sebagai pewarna tahu, sirup, pewarna jelly dan agar-agar, pewarna yogurt jagung manis (Ginting, 2008; Winarti dkk., 2008; Sayuti dkk., 2013; Ratnawati dkk., 2012), namun aplikasi ekstrak ubi unggu sebagai pewarna merah soft candy belum pernah dilaporkan.

Soft candy merupakan permen lunak yang dibuat dari campuran gula pasir, sirup gula, air, gell foaming dan bahan tambahan wana dan flavor yang dimasak pada suhu yang telah ditentukan serta memiliki tekstur lunak (Hartel \& Hartings, 2014). Soft candy indentik dengan warna cerah. Penggunaan pewarna pada soft candy banyak menggunakan pewarna sintetik karena memberikan warna lebih terang dan stabil, namun pewarna sintetik yang sering dikonsumsi dan jumlah berlebih dapat memberikan dampak kurang baik untuk kesehatan. Hal ini disebakan akan menjadi residu dalam tubuh yang bersifat karsiogenik. Pewarna alami yang kurang cerah dan stabil inilah yang menyebabkan aplikasi pewarna pada soft candy belum dilaporkan, padahal soft candy merupakan produk camilan yang banyak disukai, terutama oleh anak-anak. Hal lain kesadaran akan pangan sehat semakin meningkat.

Pewarna alami ubi ungu memiliki warna merah yang memberikan kesan terang yang menarik dan memiliki keuntungan kesehatan. Hal inilah yang memungkinan ekstrak merah ubi ungu dapat diaplikasikan pada soft candy. Antosianin ekstrak ubi ungu juga dilaporkan lebih stabil dibandingkan dengan antosianin ekstrak sorgum, kubis dan jagung merah karena lebih tinggi konsentrasi antosianin terasilasi (Ginting, 2008; Hambali dkk., 2014;Cipriano dkk., 2015). Faktor kesadaran akan pangan sehat yang sudah meningkat mendorong penganekaragaman aplikasi pewarna alami pada produk pangan, yang didukung stabilitasnya selama 
penyimpanan. Berdasarkan hal tersebut, penelitian ini bertujuan menentukan konsentrasi ekstrak pewarna alami ekstrak ubi ungu pada soft candy dan stabilitasnya selama penyimpanan.

\section{METODE PENELITIAN}

\section{Bahan}

Bahan yang digunakan meliputi: ubi jalar ungu berasal dari petani di Bangli-Bali, gula pasir (gulaku, Jakarta), sirup glukosa (rose brand), gelatin, pelarut etanol 70\% (Brataco, Jakarta), asam sitrat (Gajah, Denpasar). Bahan kimia pro analisis meliputi: natrium karbonat $\left(\mathrm{Na}_{2} \mathrm{CO}_{3}\right)$ dan Folin ciocalteau's diperoleh dari Merck, Darmstadt, Germany. Bahan kimia 1.1-diphenyl2-picryl hydrazyl (DPPH), etanol, metanol dan asam galat diperoleh dari Sigma Aldrich, St. Louis, MO, USA.

\section{Alat}

Alat yang digunakan pada penelitian meliputi: blender (Miyako, Jakarta, Indonesia), shake waterbath, oven, rotary evaporator (IKA Werke, Staufen, Jerman), spektrofotometer UV-Vis (Ishimatsu, UV- 160, Jepang) dan Homogenizer (Thermolyne, Germany). Alat gelas meliputi: pipet volume, tabung reaksi, erlenmeyer, beaker, corong, gelas ukur pyrex (Iwaki, Tokyo, Jepang).

\section{Prosedur}

Percobaan dilakukan dalam 2 tahap yaitu: 1) penentuan konsentrasi penambahan ekstrak pewarna ubi ungu pada soft candy dan 2) penentuan stabilitas pewarna merah ekstrak ubi ungu pada soft candy selama penyimpanan. Tahapan ini diawali dengan pembuatan ekstrak pewarna ubi ungu.

\section{Pembuatan ekstrak pewarna ubi ungu}

Pembuatan ekstrak pewarna ubi ungu dilakukan dengan cara: ubi ungu dibersihkan dari kotoran dengan air mengalir, penghilangan kulitnya rusak dan kotor, selanjutnya dikukus/di-bleancing pada suhu $70^{\circ} \mathrm{C}$ selama 3 menit. Langkah selanjutnya ukurannya dikecilkan dan diblender dengan ditambah air secukupnya, selanjutnya ditimbang dan ditambah pelarut 1:6 (etanol teknis $70 \%$ ditambah asam sitrat 3\%), kemudian maserasi selama 18 jam dalam shaker waterbath pada $50 \mathrm{rpm}$ suhu $30^{\circ} \mathrm{C}$. Langkah selanjutnya disaring menggunakan kain saring dilanjutkan dengan kertas saring dengan penyaringan vakum. Filtrat diambil kemudian evaporasi dengan rotary evaporator suhu waterbath $50^{\circ} \mathrm{C}$ sampai pelarut hilang atau terbentuk ekstrak kental. Ekstrak disimpan pada botol gelap suhu $-20^{\circ} \mathrm{C}$ atau siap digunakan.

\section{Pembuatan soft candy dengan penambahan pewarna ekstrak ubi ugu}

Soft candy dibuat dengan cara mencampur susu segar $(200 \mathrm{~mL})$ ditambah gula pasir $(50 \%)$, kemudian dipanaskan pada suhu $50^{\circ} \mathrm{C}$ sampai gula pasir larut, kemudian ditambah sirup glukosa (50\%) dan gelatin (8\%) dicampur sampai merata, selanjutnya suhu pemanasan ditingkatnya mencapai $100{ }^{\circ} \mathrm{C}$ selama 30 menit. Langkah selanjutnya suhu diturunkan menjadi $50{ }^{\circ} \mathrm{C}$, ditambahkan ekstrak pewarna ubi ungu sesuai perlakuan, setelah tercampur dimasukkan dalam cetakan, didinginkan suhu kamar selama 4 jam, kemudian dimasukkan refrigerator selama 12 jam sehingga terbentuk soft candy. Soft candy dikemas/ dianalisis.

\section{Rancangan percobaan}

Penelitian dilakukan dalam 2 tahap. Tahap I digunakan rancangan acak lengkap dengan perlakuan konsentrasi penambahan ekstrak pewarna ubi ungu pada soft candy, terdiri dari 5 level meliputi: ( 0 (kontrol); $0,25 ; 0,5 ; 0,75$ dan 1,0$) \%$ (berdasarkan pra penelitian, data tidak ditampilkan) dilakukan ulangan 3 kali. Tahap 2 digunakan rancangan acak lengkap dengan perlakuan suhu penyimpanan yang terdiri dari 3 level meliputi: suhu refrigerator $\left(4^{\circ} \mathrm{C}\right)$; suhu kamar $\left(27^{\circ} \mathrm{C}\right)$, dan suhu $35^{\circ} \mathrm{C}$. Pengamatan dilakukan setiap 2 hari selama 14 hari, dilakukan ulangan 3 kali.

\section{Prosedur Pengujian}

\section{Kadar antosianin}

Kadar antosianin menggunakan teknik $\mathrm{pH}$ differensial merujuk pada Giusti \& Wrolstad (2001). Pengujian diawali dengan pembuatan larutan $\mathrm{pH} 1$ dan $\mathrm{pH} \mathrm{4,5.}$

\section{Pembuatan $\mathrm{pH} 1$}

Sebanyak $1,49 \mathrm{~g} \mathrm{KCl}$ dilarutkan dalam $100 \mathrm{~mL}$ aquades serta $1,7 \mathrm{~mL} \mathrm{HCl}$ pekat dicampurkan ke dalam $100 \mathrm{~mL}$ aquades. Kemudian $25 \mathrm{~mL}$ larutan $\mathrm{KCl}$ dicampur dengan $67 \mathrm{~mL}$ larutan $\mathrm{HCl}$, selanjutnya $\mathrm{pH}$ diukur sampai mencapai $\mathrm{pH} 1$ dengan penambahan larutan $\mathrm{HCl}$.

\section{Pembuatan $\mathrm{pH} 4,5$}

Sebanyak 1,64 g sodium asetat dilarutakan dengan aquades mencapai $100 \mathrm{~mL}$, kemudian ditambah larutan $\mathrm{HCl}$ sampai mencapai $\mathrm{pH} 4,5$.

\section{Penentuan kadar antosianin}

Sampel ekstrak (1000 ppm) sebanyak 0,5 mL ditambah masing masing larutan $\mathrm{pH} 1$ atau $\mathrm{pH}$ 4,5 
sebanyak 2,5 mL, kemudian dilakukan pengukuran absorbansi pada panjang gelombang $\lambda 520$ dan $\lambda 700$ $\mathrm{nm}$. Hasil pengukuran dimasukkan dalam Persamaan 1.

$$
T A=A \times B M \times \frac{F P}{\varepsilon} \times l
$$

(Persamaan 1)

Keterangan:

$\mathrm{TA}=$ Total antosianin $(\mathrm{g} / \mathrm{L})$

$\mathrm{A}=$ Nilai absorbansi dari (A520-A700)pH1 - (A520-A700)pH 4,5

$\mathrm{BM}=$ Berat molekul sebagai sianidin 3-glikosida $(\mathrm{BM}=449,2 \mathrm{~g} /$ mol)

$\mathrm{FP}=$ Faktor Pengenceran

$\varepsilon=$ koefisien absorptivasi $(26.900 \mathrm{~L} / \mathrm{mol})$ dinyatakan sebagai sianidin 3-glikosida (BM 449,2)

$\mathrm{L} \quad=$ diameter $\operatorname{kuvet}(1 \mathrm{~cm})$

Berat antosianin dalam sampel ditentukan dengan Persamaan 2.

$K A=v \times T A / m$

(Persamaan 2)

Keterangan:

$\mathrm{KA}=$ Kadar antosianin $(\mathrm{mg} / 100 \mathrm{~g})$

$\mathrm{v} \quad=$ Volume ekstrak $(\mathrm{L})$

$\mathrm{TA}=$ Total antosianin $(\mathrm{mg} / \mathrm{L})$

\section{Total Fenolik}

Total fenolik ditentukan dengan folin ciocalteu dan standar asam galat mengacu pada Singleton \& Rossi (1985) yang didasari oleh reaksi antara senyawa antioksidan yang mempunyai cincin aromatik dengan senyawa asam heteropoli (fosfomolibdat-fosfotungstat) dari pereaksi folin ciocalteu yang menghasilkan warna biru pada spektrofotometer pada $\lambda$ 763. Pengujian dilakukan dengan cara: larutan sampel dipersiapkan dari larutan stok ekstrak etanol pada konsentrasi 100 $100 \mu \mathrm{g} / \mathrm{mL}$ (100 mg ekstrak etanol dilarutkan dengan pelarut sampel sampai volume $5 \mathrm{~mL}$ ). Sebanyak $200 \mu \mathrm{L}$ sampel, ditambah $1000 \mu \mathrm{L}$ folin ciocalteau (10\%), divortex 30 detik, inkubasi 5 menit, kemudian ditambah 800 uL $\mathrm{Na}_{2} \mathrm{CO}_{3} 7,5 \%$, divortex, inkubasi suhu kamar kondisi gelap selama 30 menit, kemudian absorbansi spektrofotometer $\lambda 763 \mathrm{~nm}$. Kurva standar dibuat dengan melarutkan asam galat dalam aquades dengan berbagai konsentrasi $10-100 \mathrm{mgL}^{-1}$. Perhitungan total fenolik menggunakan rumus persamaan regresi $y=a x$ $+\mathrm{b}$ dari standar asam gallat. Data hasil perhitungan dinyatakan dalam satuan gallic acid equivalent (GAE). Total fenolik ditentukan dengan Persamaan 3.

$\mathrm{TP}(\%)=(\mathrm{A} \times \mathrm{FP} \times \mathrm{TV} \times 100) /($ berat sampel $(\mathrm{g}))$

(Persamaan 3)
Keterangan:

A $=$ Nilai $\mathrm{x}$ dari persamaan linier standar asam galat

FP = Faktor pengenceran

$\mathrm{TV}=$ Total volume

\section{Aktivitas Antioksidan (DPPH)}

Aktivitas antioksidan berdasarkan scavenging radikal bebas DPPH yang ditentukan secara spektrofotometri dengan standar eksternal vitamin C merujuk Xu \& Chang (2007). Sampel (soft candy) sesuai perlakuan ditimbang $100 \mathrm{mg}$, diencerkan menjadi 5,0 $\mathrm{mL}$ dengan metanol 99,9\%, divortek, disentrifuge $3000 \mathrm{rpm} 15$ menit, disaring sampai diperoleh filtrat. Filtrat dan standar dipipet $0,5 \mathrm{~mL}$ ditambahkan $3,5 \mathrm{ml}$ DPPH (2,2-diphenyl-1-picrylhydrazyl) $0.1 \mathrm{mM}$ (dalam pelarut metanol 99,9\%) pada tabung reaksi, kemudian divorteks. Sampel diinkubasi pada suhu $25^{\circ} \mathrm{C}$ selama 30 menit. Selanjutnya diukur absorbansinya pada panjang gelombang $517 \mathrm{~nm}$. Kontrol dibuat dengan mengganti sampel dengan pelarut metanol. Persentase scavenging radikal bebas DPPH sebagai nilai y ditentukan melalui Persamaan 4.

$\%$ scavenging radikal bebas DPPH $(y)=\frac{\text { Abs kontrol-Abs sampel }}{\text { Abs kontrol }} \times 100 \%$

(Persamaan 4)

Keterangan:

Abs kontrol = Absorbansi dari sampel yang diganti dengan pelarut DPPH

Abs sampel $=$ Absorbansi sampel uji

Hasil $y$ tersebut dimasukkan dalam persamaan linier dari kurva kalibrasi vitamin C (Ascrobic acid) pada konsentrasi $(0,100,200,300,400,500)$ ppm untuk mendapatkan nilai $\mathrm{x}$, kemudian aktivitas antioksidan soft candy equivalen vitamin C ditentukan melalui Persamaan 5.

Aktivitas antioksidan soft candy equivalen vitamin C $=\frac{X \times F P \times T V}{M} \times 100 \%$

(Persamaan 5)

Keterangan:

$X \quad=$ Nilai $x$ dari persamaan linier vitamin $C(\mathrm{mg} / \mathrm{L})$

$\mathrm{FP}$ = Faktor pengenceran

$\mathrm{TV}=$ Total volume $(\mathrm{L})$

$\mathrm{M}$ = Berat sampel $(\mathrm{mg})$

\section{Analisis Sensori}

Analisis sensori digunakan analisis kesukaan terhadap artibut warna, aroma, tekstur, rasa dan penerimaan keseluruhan dengan nilai skor 1-7 (sangat tidak suka- sangat suka). 


\section{Pengukuran Nilai $L$ a* dan $b *$}

Pengukuran dilakukan merujuk Francis (2002) dengan cara meletakan sampel pada wadah sampel, kemudian wadah berisi sampel diletakkan di atas sensor kromameter Minolta, lalu ditekan tombol pengukuran dan data nilai $L^{*}, a^{*}, b^{*}$ akan muncul pada layar. Nilai $\mathrm{L}$ (lightness) a* (red), b* (yellow).

\section{Analisis Data}

Data dari masing-masing parameter uji dari tiga kali ulangan dianalisis dan disajikan dalam bentuk nilai rata-rata \pm standar deviasi. Analisis data menggunakan analysis of variance (ANOVA). Analisis dilanjutkan jika terjadi pengaruh perlakuan terhadap paameter uji. Uji lanjut digunakan analisis Duncan Multiple Range Test (DMRT) dengan tingkat signifikansi $5 \%(p<0,05)$ menggunakan program SPSS for windows 1.9.

\section{HASIL DAN PEMBAHASAN}

\section{Kadar Antosinin}

Perlakuan konsentrasi ekstrak antosianin ubi ungu berpengaruh secara signifikan $(p<0,05)$ pada kadar antosianin soft candy yang dihasilkan. Kadar antosianin soft candy ditampilkan pada Tabel 1.

Tabel 1. Kadar antosianin soft candy

\begin{tabular}{ll}
\hline Perlakuan & Kadar antosianin $(\mathrm{mg} / \mathrm{kg})$ \\
\hline K0 & $0,00 \pm 0,00^{\mathrm{e}}$ \\
K1 & $78,15 \pm 0,01^{\mathrm{d}}$ \\
K2 & $111,72 \pm 0,83^{\mathrm{c}}$ \\
K3 & $124,74 \pm 0,55^{\mathrm{b}}$ \\
K4 & $425,32 \pm 0,81^{\mathrm{c}}$ \\
\hline
\end{tabular}

Keterangan: $\mathrm{KO}=$ tanpa penambahan ekstrak; $\mathrm{K} 1$ = penambahan ekstrak 0,25\%; K2 = penambahan ekstrak 0,50\%; $\mathrm{K} 3=$ penambahan ekstrak 0,75\%; K4 = penambahan ekstrak $1 \%$; huruf yang berbeda pada kolom yang sama menunjukkan perbedaan yang signifikan $(p<0,05)$; data dalam bentuk nilai rata-rata dan standar deviasi, $\mathrm{n}=3$

Tabel 1 menunjukkan bahwa kadar antosianin tertinggi pada perlakuan $\mathrm{K} 4(1 \%)$ sebesar $425,32 \mathrm{mg} / \mathrm{kg}$ bahan dan terendah pada $\mathrm{KO}$ sebesar $0 \mathrm{mg} / \mathrm{kg}$, semakin tinggi konsentrasi ekstrak antosianin ubi ungu yang ditambahkan, kadar antosianin meningkat. Peningkatan konsentrasi ekstrak antosianin menunjukkan semakin besar kadar antosianin soft candy. Hal ini dapat dilihat dari warna softcandy yang semakin merah cerah dengan semakin tingginya kadar ekstrak ubi ungu yang ditambahkan. Antosianin merupakan pigmen alami yang memberikan kesan warna merah selain ungu dan biru (Burton-Freeman dkk., 2016) Hal ini dapat menunjukkan proses pemberian ekstrak yang dilakukan pada akhir (suhu $50^{\circ} \mathrm{C}$ ) belum menyebabkan degradasi antosianin. Hal ini didukung Bastos dkk. (2015) melaporkan degradasi antosianin terjadi pada suhu diatas $50^{\circ} \mathrm{C}$. Kestabilan antosianin dapat disebabkan adanya gula yang tinggi pada soft candy. Penelitian ini selaras dengan Tsai dkk. (2004) yang melaporkan adanya gula pada konsentrasi yang tinggi pada ekstrak antosianin rosella pada suhu $<50^{\circ} \mathrm{C}$ dapat melindungi antosianin dari degradasi. Sayuti dkk. (2013), melaporkan semakin tinggi konsentrasi penambahan ekstrak ubi ungu pada yoghurt jagung manis dapat menyebabkan warna yang semakin cerah dan lebih disukai, sebelumnya Ginting (2008), melaporkan antosianin ekstrak ubi ungu lebih stabil terhadap perubahan suhu dibandingkan dari ekstrak sorgum. Hal ini disebabkan konsentrasi antosianin terasilasi lebih tinggi (Cipriano dkk., 2015). Bentuk antosianin terasilasi dari ubi ungu akan meningkatkan kestabilan selama proses pengolahan. Hal ini didukung oleh Bastos dkk. (2015) melaporkan kestabilan antosianin menurun karena terjadi degradasi glikosidik pada antosianin, namun bentuk antosianin terasilasi dapat meningkatkan stabilitasnya.

\section{Kadar Fenolik}

Perlakuan konsentrasi ekstrak antosianin ubi ungu berpengaruh pada kadar fenolik soft candy $(p<0,05)$. Kadar fenolik soft candy ditampilkan pada Tabel 2.

Tabel 2. Kadar fenolik soft candy

\begin{tabular}{cc}
\hline Perlakuan & Kadar fenolik $(\mathrm{g} / 100 \mathrm{~g})$ \\
\hline K0 & $0,00 \pm 0,00 \mathrm{~d}$ \\
K1 & $0,63 \pm 0,02 \mathrm{c}$ \\
K2 & $0,64 \pm 0,02 \mathrm{c}$ \\
K3 & $0,73 \pm 0,02 \mathrm{~b}$ \\
K4 & $2,77 \pm 0,02 \mathrm{a}$ \\
\hline
\end{tabular}

Keterangan: $\mathrm{KO}=$ tanpa penambahan ekstrak; $\mathrm{K} 1$ = penambahan ekstrak 0,25\%; $\mathrm{K} 2=$ penambahan ekstrak $0,50 \% ; \mathrm{K} 3=$ penambahan ekstrak $0,75 \% ; \mathrm{K} 4=$ penambahan ekstrak $1 \%$; huruf yang berbeda pada kolom yang sama menunjukkan perbedaan yang signifikan $(p<0,05)$; data dalam bentuk nilai ratarata dan standar deviasi, $\mathrm{n}=3$

Tabel 2 menunjukkan kadar fenolik tertinggi pada perlakuan K4 (1\%) sebesar 2,77 mg/100 g dan terendah pada perlakuan KO $(0 \%)$ sebesar 0,00 $\mathrm{mg} / 100 \mathrm{~g}$. Hasil ini seiring dengan kadar antosianin. 
Hal ini menunjukkan kadar total fenolik lebih banyak ditentukan oleh kadar antosianin. Antosianin merupakan salah satu komponen fenolik (Burton-Freeman dkk., 2016).. Troung dkk. (2007) melaporkan senyawan fenolik non antosianin yang ditemukan pada ekstrak ubi ungu meliputi: caffeic acid, chlorogenic acid, 4,5-di$O$-caffeoylquinic acid, 3,5-di-O-caffeoylquinic acid, and 3,4-di-O-caffeoylquinic. Senyawa fenolik jenis antosianin yang dominan ditemukan pada ekstrak ubi ungu adalah bentuk konjugasi dari cyanidin dan peonidin (Wang dkk., 2017; Gras dkk., 2017; Wang dkk., 2017).

\section{Aktivitas Antioksidan}

Perlakuan konsentrasi ekstrak antosianin ubi ungu berpengaruh terhadap aktivitas antioksidan soft candy sebagai persentase scavenging radikal bebas DPPH $(p<0,05)$. Aktivitas antioksidan (DPPH) soft candy dilihat pada Tabel 3.

Tabel 3. Aktivitas antioksidan soft candy (DPPH)

\begin{tabular}{cc}
\hline Perlakuan & Aktivitas antioksidan (g AAE/100g) \\
\hline K0 & $0,42 \pm 0,01 \mathrm{e}$ \\
K1 & $0,62 \pm 0,02 \mathrm{~d}$ \\
K2 & $0,76 \pm 0,02 \mathrm{c}$ \\
K3 & $0,81 \pm 0,02 \mathrm{~b}$ \\
\hline
\end{tabular}

Keterangan: $\mathrm{KO}=$ tanpa penambahan ekstrak; $\mathrm{K} 1=$ penambahan ekstrak 0,25\%; K2 = penambahan ekstrak 0,50\%; K3 = penambahan ekstrak 0,75\%; K4 = penambahan ekstrak 1\%; AAE= Ascorbic Acid Equivalent; huruf yang berbeda pada kolom yang sama menunjukkan perbedaan yang signifikan $(p<0,05)$; data dalam bentuk nilai rata-rata dan standar deviasi, $\mathrm{n}=3$
Tabel 3 menunjukkan aktivitas antioksidan tertinggi pada perlakuan $\mathrm{K} 4(1 \%)$ sebesar $0,824 \mathrm{~g} \mathrm{AAE} / 100 \mathrm{~g}$ dan terendah pada perlakuan $\mathrm{KO}(0 \%)$ sebesar $0,419 \mathrm{~g}$ $\mathrm{AAE} / 100 \mathrm{~g}$. Aktivitas antioksidan soft candy disebabkan adanya senyawa bersifat antioksidan seperti senyawa atosianin dan senyawa fenolik non-antosianin selain vitamin $\mathrm{C}$ yang ditunjukaan dengan hasil yang selaras dengan kadar antosianin dan total fenolik. Aktivitas antioksidan senyawa tersebut berdasarkan kemampuan scavenging radikal bebas (DPPH) yang ditunjukkan adanya perubahan warna ungu ke kuning (penurunan nilai absorbansi), setelah ditambahkan ekstrak ubi ungu. Semakin tinggi kadar ekstrak ubi ungu pada soft candy semakin rendah nilai abosorbansi atau aktivitas antioksidan semakin besar. Senyawa antosianin atau fenolik dapat memiliki aktivitas antioksidan karena memiliki gugus hidroksil dan sturktur terkonjugasi. Antosianin atau senyawa fenolik akan mentrasfer atom hidrogen kepada radikal bebas DPPH, sehingga membentuk senyawa yang bersifat lebih stabil dan DPPH tereduksi (berwarna kuing). Hasil ini selaras dengan Retnati (2009), melaporkan penambahan ekstrak ubi ungu pada yoghurt dapat meningkatkan aktivitas antioksidan dibandingkan ubi jalar orange dan putih yang tidak kaya antosianin.

\section{Hasil Evaluasi Sensori}

Perlakuan konsentrasi ekstrak antosianin ubi ungu berpengaruh terhadap hasil evaluasi sensori: warna, tekstur, rasa dan penerimaan keseluruhan soft candy $(p<0,05)$, tetapi tidak pada aroma $(p>0,05)$. Hasil nilai sensori soft candy ditampilkan pada Tabel 4.

Tabel 4 menunjukkan nilai sensori kesukaan warna terendah pada $\mathrm{K} 1(0,25 \%)$ dengan nilai 5,21 (agak

Tabel 4. Hasil nilai sensori soft candy

\begin{tabular}{lcrcrr}
\hline Perlakuan & \multicolumn{5}{c}{ Nilai rata rata } \\
\cline { 2 - 6 } & Warna & Aroma & Tekstur & Rasa & $\begin{array}{c}\text { Penerimaan } \\
\text { keseluruhan }\end{array}$ \\
\hline K0 & $5,31 \pm 1,40 \mathrm{a}$ & $4,46 \pm 1,22 \mathrm{a}$ & $5,46 \pm 0,94 \mathrm{a}$ & $5,15 \pm 1,38 \mathrm{a}$ & $5,23 \pm 0,93 \mathrm{ab}$ \\
K1 & $5,21 \pm 1,22 \mathrm{~b}$ & $4,54 \pm 1,27 \mathrm{a}$ & $5,31 \pm 1,28 \mathrm{a}$ & $5,15 \pm 1,03 \mathrm{a}$ & $5,15 \pm 0,95 \mathrm{bc}$ \\
K2 & $5,46 \pm 1,02 \mathrm{a}$ & $4,46 \pm 1,28 \mathrm{a}$ & $5,31 \pm 1,28 \mathrm{a}$ & $5,00 \pm 1,38 \mathrm{a}$ & $5,15 \pm 0,95 \mathrm{bc}$ \\
K3 & $6,08 \pm 0,95 \mathrm{a}$ & $4,61 \pm 1,14 \mathrm{a}$ & $5,85 \pm 0,92 \mathrm{a}$ & $5,46 \pm 1,15 \mathrm{a}$ & $5,92 \pm 0,86 \mathrm{ab}$ \\
K4 & $5,54 \pm 1,08 \mathrm{a}$ & $4,23 \pm 1,09 \mathrm{a}$ & $4,77 \pm 1,17 \mathrm{~b}$ & $4,15 \pm 1,23 \mathrm{~b}$ & $4,38 \pm 1,16 \mathrm{c}$ \\
\hline
\end{tabular}

Keterangan: $\mathrm{KO}$ = tanpa penambahan ekstrak; $\mathrm{K} 1$ = penambahan ekstrak 0,25\%; K2 = penambahan ekstrak 0,50\%; K3 $=$ penambahan ekstrak 0,75\%; $\mathrm{K} 4$ = penambahan ekstrak 1\%; nilai kesukaan dari $1-7 ; 1=$ sangat tidak suka; 2 = tidak suka; 3 = agak tidak suka; 4 = netral; 5 = agak suka; 6 = suka; 7 = sangat suka; huruf yang berbeda pada kolom yang sama menunjukkan perbedaan yang signifikan $(p<0,05)$; data dalam bentuk nilai rata-rata dan standar deviasi, $\mathrm{n}=20$; 
suka), tertinggi pada $\mathrm{K} 3(0,75 \%)$ dengan nilai kesukaan 6,08 (suka), namun tidak berbeda dengan K2 (0,50\%), K4 $(1,0 \%)$ dan kontrol. Hal ini menunjukkan konsentrasi ekstrak pewarna ubi ungu pada konsentrasi mulai dari $0,5 \%$ ke atas sudah dapat memberikan kesan warna merah terang yang disukai, sementara pada konsentrasi $0,25 \%$ belum memberikan kesan warna merah terang. Warna soft candy pada konsentrasi 0,25\% menunjukkan warna pink yang lembut.

Aroma soft candy setelah ditambahkan ekstrak pewarna ubi ungu tidak memberikan perbedaan aroma. Hal ini dapat ditunjukkan dari tingkat kesukaan terhadap aroma yang tidak berbeda diantara perlakuan. Nilai tingkat kesukaan terhadap aroma pada kisaran 4,23-4,61 (netral - agak suka).

Kesukaan terhadap tekstur soft candy menunjukkan terendah pada $\mathrm{K} 4$ (1\%) dengan nilai kesukaan 4,77 (agak suka), tertinggi pada K3 $(0,75 \%)$ dengan nilai kesukaan 5, 85 (suka). Tingkat kesukaan tekstur soft candy pada konsentrasi 0,75\% tidak berbeda dengan konsentrasi 0,25-0,5\%. Hal ini menunjukkan konsentrasi penambahan ekstrak pewarna ubi ungu dapat merubah tekstur setelah konsentrasi $0,75 \%$. Tekstur soft candy pada konsentrasi $1 \%$ (K4) menunjukkan tekstur yang lebih lunak dibandingkan dengan yang laiinya. Hal ini kemungkinan dapat mempengaruhi tingkat kesukaan

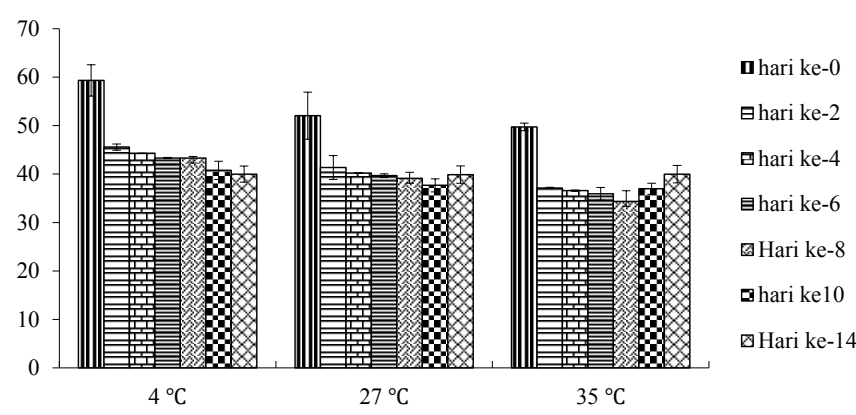

Gambar 2. Nilai $L$ (kecerahan) soft candy selama penyimpanan (data dinyatakan dalam rata-rata $\pm \mathrm{SD} ; p<0,05 ; \mathrm{n}=3$ )

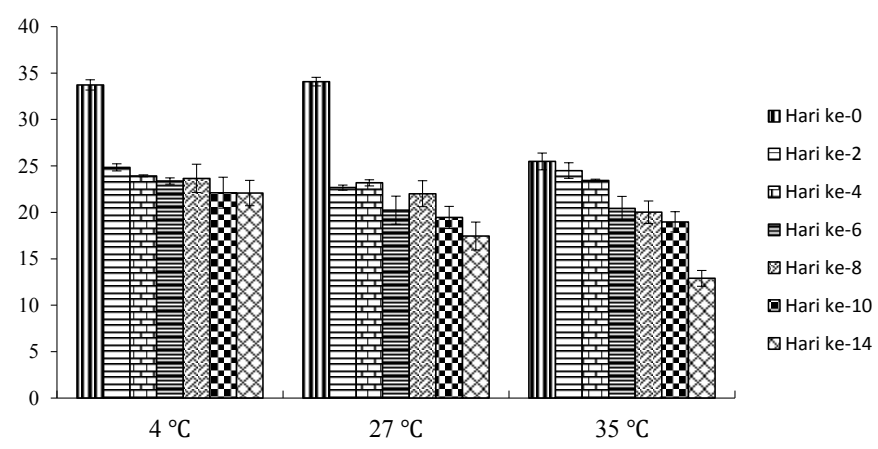

Gambar 3. Nilai a* (kemerahan) soft candy selama penyimpanan (data dinyatakan dalam rata-rata $\pm \mathrm{SD} ; p<0,05 ; \mathrm{n}=3$ )

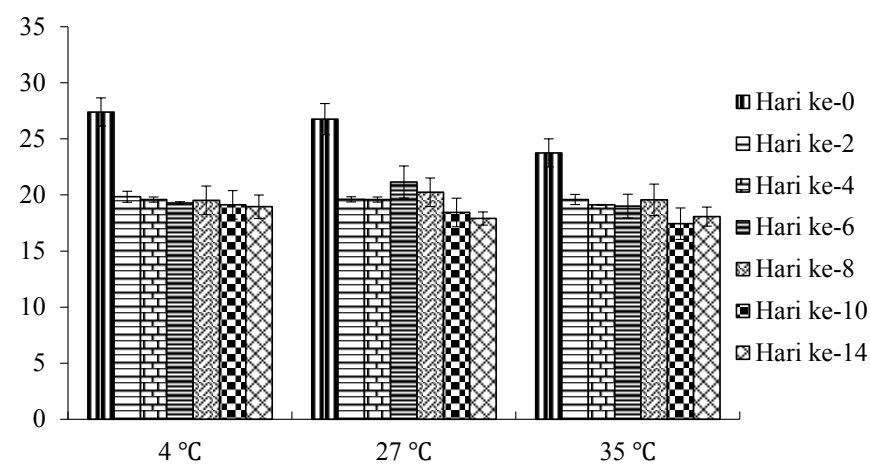

Gambar 4. Nilai b* (kekuningan) soft candy selama penyimpanan (data dinyatakan dalam rata-rata $\pm \mathrm{SD}$; huruf yang berbeda pada suhu yang sama menunjukkan perbedaan yang signifikan $p<0,05 ; \mathrm{n}=3$ )

terahadap tekstur lebih rendah. Panelis lebih menyukai tekstur lebih keras.

Nilai kesukaan panelis terhadap rasa terendah pada K4 (1\%) dengan nilai kesukaan 4,05 (netral) dan tertinggi pada $\mathrm{K} 3(0,75 \%)$ dengan nilai kesukaan 5,46 (agak suka), sementara nilai kesukaan rasa pada K1 $(0,25 \%)$ dan K2 $(0,5 \%)$ tidak berbeda dengan K3. $\mathrm{Hal}$ ini menunjukkan pada konsentrasi $1 \%$ telah terjadi perubahan rasa yang menurunkan kesukaan panelis. Rasa soft candy pada konsentrasi $1 \%$ terasa asam yang kemungkinan kurang disukai. Rasa asam disebabkan oleh ekstraksi pewarna merah antosianin dilakukan pada kondisi asam dengan menambahkan asam sitrat sehingga pada konsentrasi yang lebih tinggi dapat mempengaruhi rasa soft candy.

Penerimaan keseluruhan soft candy menunjukkan tertinggi pada K3 $(0,75 \%)$ dengan nilai kesukaan 5,92 (suka) dan terendah pada K4 (1\%) dengan nilai kesukaan 4,38 (netral). Nilai kesukan pada K3 $(0,75 \%)$ tidak berbeda dengan kontrol (penambahn pewarna merah komersial). Hal ini menunjukkan konsentrasi penambahan ekstrak $0,75 \%$ pada soft candy memberikan tingkat penerimaan yang lebih baik dibandingkan konsentrasi $1 \%$.

\section{Stabilitas Soft Candy Selama Penyimpanan}

Indiktor stabilitas ekstrak antosianin ubi ungu sebagai bahan pewarna soft candy selama penyimpanan digunakan nilai $L$, a* dan $b^{*}$. Nilai $L$ (kecerahan), a* (kemerahan) dan b* (kekuningan). Nilai L, a*, b* selama penyimpanan ditampilkan pada Gambar 2, 3 dan 4.

Gambar 2 menjelaskan nilai L soft candy pada penyimpanan suhu $4{ }^{\circ} \mathrm{C}$ (refrigerator), $27{ }^{\circ} \mathrm{C}$ (suhu kamar) mengalami penurunan selama penyimpanan dari hari ke-0 sampai hari ke-12, sedangkan pada suhu $35{ }^{\circ} \mathrm{C}$ sampai hari ke-8, setelah itu mengalami 
peningkatan nilai L yaitu dari hari ke 10 sampai ke12, namun kenaikannya tidak signifikan. Hal ini menunjukkan penurunan nilai $\mathrm{L}$ pada suhu $4^{\circ} \mathrm{C}$ dan $27^{\circ} \mathrm{C}$ seiring bertambahnya waktu penyimpanan yang mengindikaskan terjadi degradasi antosianin soft candy yaitu warna merah cerah (kation flavilium) softcandy menjadi carbinol pseudobase (kurang berwarna/ kuning pucat) selanjutnya menjadi chalcone ( kurang berwarna) (Burton-Freeman dkk., 2016). Perubahan warna merah ke arah chalcone dapat mempengaruhi nilai L. Namun, pada suhu $35^{\circ} \mathrm{C}$ setelah hari ke-12 terjadi peningkatan diduga efek suhu yang lebih tinggi akan menyebabkan degradasi antosianin bentuk kation flavilium yang membentuk karbinol yang tidak berwarna yang meningkatkan kecerahan. Degradasi antosianin menjadi bentuk carbinol akan terus belangsung menjadi chalcone yang tiadak berwarna menjadi putih/ bening. Perubahan antosianin menjadi chalcone dapat meningkatkan tingkat kecerahan sampel sehingga nilai L-nya menunjukkan nilai yang lebih tinggi. Koswara (2009) melapokan degradasi antosianin akan menurunkan nilai $L$ namun akan diikuti peningkatan nilai L. Peningkatan nilai L selaras dengan Ginting (2008), melaporkan nilai L ekstrak ubi ungu pada sirup pada akhir penyimpanan mengalami peningkatan nilai L. Degradasi wana merah atau struktur kation flavilium antosianin menjadi bentuk coklat karena telah terjadi kopigmentasi.

Gambar 3 menunjukkan nilai a* (kemerahan) soft candy pada suhu penyimpanan $4{ }^{\circ} \mathrm{C}$ (refrigerator), 27 ${ }^{\circ} \mathrm{C}$ (suhu kamar) dan suhu $35^{\circ} \mathrm{C}$ mengalami penurunan sampai penyimpanan hari ke-12. Nilai a* menunjukkan derajat kemerahan atau kehijauan. Nilai a positif menunjukkan sampel memiliki derajat kemerahan, sementara a negatif menunjukkan derajat kehijaun. Peningkatan degradasi antosianin menjadi bentuk cabinol pseudobase (tidak berwarna/kuning pucat) selanjutnynya memebentuk chalcone (kurang berwarna) akan menyebabkan penurunan nilai a. Perubahan ini dapat terjadi karena hidrolisis pada ikatan glikosidik antosianin sehingga menghasilkan aglikon yang tidak stabil selanjutnya cincin aglikon terbuka membentuk gugus carbinol dan chalcone (Burton-Freeman dkk., 2016). Hasil ini didukung Hariadi dkk. (2018), melaporkan antosianin ubi ungu mengalami degradasi seiring meningkatnya waktu penyimpanan. Semakin lama waktu penyimpanan juga dapat mempengaruhi pH. Castañeda-ovando dkk. (2009), melaporkan pada pH 1 sampai dengan pH 2 antosianin berbentuk kation flavilium yang memberi warna merah, peningkatan $\mathrm{pH}$ yaitu antara $\mathrm{pH}$ 2-4 antosianin berbentuk quinoidal blue. Pada pH 5 sampai 6 berbentuk carbinol pseudobase (warna berkurang) dan chalcone (kuning pucat). Di atas
pH 7 antosianin mengalami degradasi menjadi aldehid dan asam fenolik atau diketon.

Gambar 4 menjelaskan nilai b* (kekuningan) softcandy pada suhu penyimpanan refrigerator (4 $\left.{ }^{\circ} \mathrm{C}\right)$ dan suhu kamar $\left(27^{\circ} \mathrm{C}\right)$ selama penyimpanan mengalami penurunan sampai hari-12, sedangkan pada penyimpanan suhu $35^{\circ} \mathrm{C}$ terjadi penurunan sampai hari ke-10, pada hari ke-12 ada kecendrungan peningkatan walaupun tidak berbeda signifikan dengan hari ke-10. Nilai $b$ menunjukkan tingkat kekunigan atau kebiruan. Nilai b* positif menunjukkan nilai derajat kekuningan, nilai $b$ negatif menunjukkan derajat kebiruan. Antosianin dapat menimbulkan warna merah selain ungu dan biru. Penurunan nilai $b^{*}$ selama penyimpanan karena adanya degradasi antosianin yang berwarna merah (bentuk kation flavilium) menjadi kurang berwarna (carbinol pseudobase) kemudian membentuk chalcone (kurang berwarna/kuning pucat), sementara pada suhu $35{ }^{\circ} \mathrm{C}$ terjadi penurunan sampai hari ke-10 dan pada hari ke-12 cendrung meningkat. Hal ini menunjukkan pada suhu lebih tinggi degradasi antosianin lebih cepat dan tidak saja akan meningkatkan chalcone (kuning pucat) tetapi akan meningkatkan senyawa turunan seperti 2,4,6-trihidroksicenzaldehid dan asam benzoat tersubstitusi yang mungkin dapat meningkatkan nilai $b^{*}$.dengan penuruan nilai a* (kemerahan) dari soft candy sebagai tanda kerusakan antosianin sebagai bahan pewarna merah dari ekstrak ubi ungu. Cahaya dapat mempengaruhi degradasi antosianin ke arah chalcone yang tidak berwarna (kuning pucat). Energi yang dikelurakan dari cahya dapat menyebabkan reaksi fitokimia atau fotooksidasi dan paparan cahaya yang lama menyebabkan terjadi degradasi lanjutan terbentuk senyawa turunan seperti 2,4,6-trihidroksicenzaldehid dan asam benzoat tersubstitusi. Senyawa chalcone dan turunan tersebut akan meningkat seiring meningkatnya suhu penyimpana. Perubahan tersebut dapat menurunkan tingkat kemerahan dan meningkatkan nilai kekuningan (Koswara, 2009). Dengan demikian, penyimpanan suhu rendah dapat memperlambat proses degradasi antosianin dibandingkan suhu lebih tinggi.

\section{KESIMPULAN}

Ekstrak ubi ungu sebagai pewarna pada soft candy dapat meningkatkan aktivitas antioksidan yang ditunjang dengan adanya antosianin dan senyawa fenolik. Soft candy yang diterima panelis terbaik pada penambahan ekstrak ubi ungu sebesar $0,75 \%$. Stabilitas warna merah ekstrak ubi ungu pada soft candy selama penyimpanan lebih baik pada suhu $4^{\circ} \mathrm{C}$ dan suhu kamar $\left(27^{\circ} \mathrm{C}\right.$ ) dibandingkan suhu $35^{\circ} \mathrm{C}$. 


\section{KONFLIK KEPENTINGAN}

Penulis nyatakan bahwa artikel ini asli, belum pernah dipublikasikan, dan bebas dari konflik kepentingan.

\section{DAFTAR PUSTAKA}

Bastos, R. ., De Oliveira, K. K. ., Melo, E. D. ., \& De Lima, V. L. A. . (2015). Stability of Anthocyanins from AgroIndustrial Residue of Isabel Garape Grown In Sao Francisco Valley, Brazil. Rev.Bras.Frutic, 39(1), 1-8. http://dx.doi.org/10.1590/0100-29452017564

BPS Bali. (2015). Produksi ubi jalar di bali 2015. Denpasar.

Burton-Freeman, B., Sandhu, A., \& Edirisinghe, I. (2016). Anthocyanins. In Nutraceuticals (pp. 489-500).

Castañeda-ovando, A., Pacheco-hernández, M. D. L., Páezhernández, M. E., Rodríguez, J. A., \& Galán-vidal, C. A. (2009). Chemical studies of anthocyanins: A review. J. Food Chem., 113(4), 859-871. https://doi. org/10.1016/j.foodchem.2008.09.001

Cipriano, P. ., Ekici, L., Barnes, R. ., Gomes, C., \& Talcott, S. . (2015). Pre-heating and polyphenol oxidase inhibition impact on extraction of purple sweet potato anthocyanins. Food Chem, 180, 227-234. https://doi. org/10.1016/j.foodchem.2015.02.020

Finosh, G. T., \& Jayabalan, M. (2013). Reactive oxygen species-Control and management using amphiphilic biosynthetic hydrogels for cardiac applications. Advan in Biosci \& Biotechnol, 04(12), 1134-46.

Gilbert, D. . (2006). Fifty Years of Radical Ideas. Annals of the New York Academy of Scie, 899(1), 1-14.

Ginting, E. (2008). Potensi Ekstrak Ubi Jalar Ungu Sebagai Bahan Pewarna Alami Sirup. In Prosiding Seminar Hasil Pertanian Aneka Kac dan Um (pp. 755-767).

Giusti, M. M., \& Wrolstad, R. E. (2001). Characterization and Measurement of Anthocyanins by UV - Visible Spectroscopy. Current Protocols in Food Anal Chem, F1.2.1-F1.2.13.

Gras, C. C., Nemetz, N., Carle, R., \& Schweiggert, R. M. (2017). Anthocyanins from purple sweet potato ( Ipomoea batatas ( $L$.) Lam .) and their color modulation by the addition of phenolic acids and food-grade phenolic plant extracts. Food Chem, 235, 265-274. DOI: 10.1016/j. foodchem.2017.04.169

Halliwell, B. (1994). or Consequence? Lancet, 344(10), 721724.

Hambali, M., Mayasari, F., \& Noermansyah, F. (2014). Ekstraksi Antosianin dari Ubi Jalar dengan Variasi Konsentrasi Solven, Dan Lama Waktu Ekstraksi. J Teknik Kimia, 20(2), 25-35.
Hariadi, H., Sunyoto, M., Nurhadi, B., \& Karuniawan, A. (2018). Comparison of phytochemical characteristics pigmen extract ( Antosianin ) sweet purple potatoes powder ( Ipomoea batatas $\mathrm{L}$ ) and clitoria flower ( Clitoria ternatea ) as natural dye powder. J Pharma \& Phytochem., 7(4), 3420-3429.

Hartel, R., \& Hartings, M. (2014). Candy Chemistry. In Sweet Science: Having Fun with Candy Chemistry (pp. 1-36).

Ina, P.T., Ekawati, G.A. dan Puspawati, G.A.K.D. (2014). Efek Waktu Ekstraksi terhadap Aktivitas Antioksidan, Total Fenol dan Kadar Antosianin Ekstrak Ubi Ungu. Proseding seminar Nasional Hasil Hasil Penelitian, tanggal 27-28 Pebruari Unmas dengan Flipmas, Badung, Bali.

Iriyanti, Y. (2012). Subtitusi Tepung Ubi Ungu Dalam Pembuatan Roti Manis, Donat Dan Cake Bread. Universitas Negeri Yogyakarta, Yogyakarta.

Koswara, S. M. (2009). Produksi : Teknologi Pengolahan Sayuran Dan Buah-Buahan, 1-59.

Ratnawati, D., Maryanti, E., \& Sentani, A. M. (2012). Aplikasi Ekstrak Umbi Ubi Jalar Ungu ( Ipomoea batatas var ayamurasaki ) Sebagai Pengawet dan Pewarna Alami Tahu. J Gradien, 8(1), 739-745.

Retnati. (2009). Pengaruh Penambahan Ekstrak Berbagai Jenis Ubi Jalar (Ipomoea batatas L) terhadap Jumlah Sel dan Aktivitas Antioksidan Yoghurt. Universitas Sebelas Maret.

Retno, S., Suwandi, Nuryati, L., Waryanto, B., \& Akbar. (2016). Outlook Ubi Jalar 2016. Pusat Data dan Sistem Informasi Pertanian, Kementrian Pertanian.

Sayuti, I., Wulandari, S., \& Sari, D. K. (2013). Penambahan Ekstrak Ubi Jalar Ungu ( Ipomoea batatas var . Ayamurasaki ) dan Susu Skim terhadap Organoleptik Yoghurt Jagung Manis (Zea mays L .Saccharata) dengan Menggunakan Inokulum Lactobacillus acidophilus dan Bifidobacterium sp. In Prosiding Semirata FMIPA Universitas Lampung (pp. 399-410).

Singleton, V. ., \& Rossi, J. A. j. (1985). Colorimetry of Total Phenolic with Phosphomolybdic-Phosphotungstic Acid Reagent. Amer.J.Enol. Vitcult, 16(2).

Troung, V. D., McFeeters, R. E., Thompson, R. T., Dean, L. .\& Shofran, B. (2007). Phenolic Acid Content and Composition in Leaves and Roots of Common Commercial Sweetpotato ( Ipomea batatas L .) Cultivars in the United States. J Food Chemic \& Toxic, 70(6), C343-C349. DOI: 10.1111/j.1750-3841.2007.00415.x

Tsai, P.-J., Hsieh, Y.-Y., \& Huang, T.-C. (2004). Effect of Sugar on Anthocyanin Degradation and Water Mobility in a Roselle Anthocyanin Model System Using 170 NMR. J.Agric. Food Chem, 52, 3097-3099. DOI: 10.1021/ jf0306587

Wang, L., Zhao, Y., Luo, C.-L., Deng, A.-P., Zhang, Z.-C., \& Zhang, J.-L. (2017). Characterization and hepatoprotective 
activity of anthocyanins from purple sweet potato (Ipomoea batatas L. cultivar Eshu No. 8). J Food \& Drug Anal, 25, 607-618. https://doi.org/10.1016/j. jfda.2016.10.009

Winarti, S., Sarofa, U., \& Anggrahini, D. (2008). Ekstraksi dan Stabilitas Warna Ubi Jalar Ungu (Ipomoea batatas L .,) sebagai Pewarna Alami. Jurnal Teknik Kimia, 3(1), 207214.
Xu, B. ., \& Chang, S. K. C. (2007). A Comparative Study on Phenolic Profiles and Antioxidant Activities of Legumes. J Food Sci, 72(2), S159-S166. DOI: 10.1111/j.17503841.2006.00260.x 